\title{
Assessment of Genetic Diversity of Pawpaw (Asimina triloba) Cultivars with Intersimple Sequence Repeat Markers
}

\author{
Kirk W. Pomper, ${ }^{1}$ Sheri B. Crabtree, ${ }^{2}$ Shawn P. Brown, ${ }^{3}$ Snake C. Jones, ${ }^{3}$ and Tera M. Bonney ${ }^{4}$ \\ Kentucky State University, Land Grant Program, 129 Atwood Research Facility, Frankfort, KY 40601-2355
}

Desmond R. Layne ${ }^{5}$

Clemson University, Department of Horticulture, Clemson, SC 29634-0375

AdDITIONAL INDEX wORDS. kentucky banana, ISSR, molecular markers, DNA finger printing, cultivar identification

Abstract. The pawpaw [Asimina triloba (L.) Dunal.] is a tree fruit native to many areas of the southeastern and midwestern United States. Kentucky State University (KSU) is designated as a satellite repository for Asimina for the U.S. Department of Agriculture (USDA), National Plant Germplasm System (NPGS). An assessment of the level of genetic diversity in cultivated pawpaw would assist in development of the future germplasm repository collection strategies for cultivar improvement. The objectives of this study were to identify intersimple sequence repeat (ISSR) markers that segregate in a simple Mendelian fashion and to use these markers to assess genetic diversity in 19 pawpaw cultivars. Leaf samples from the 34 progeny of controlled crosses (1-7-1 $\times 2-54$ and reciprocal) and the parents were collected, DNA was extracted, and subjected to the ISSR methodology using the University of British Columbia microsatellite primer set \#9. Seven primers yielded 11 Mendelian markers with either a 3:1 or 1:1 ratio that was confirmed by chi-square analysis. Analysis of genetic diversity using 10 of the ISSR markers from 19 pawpaw cultivars revealed a moderate to high level of genetic diversity, with a percent polymorphic loci $\mathrm{P}=80$ and an expected heterozygosity $\mathrm{He}=0.358$. These diversity values are higher than those reported for cultivated pawpaw using isozyme or randomly amplified polymorphic DNA (RAPD) markers, indicating that the ISSR marker methodolgy has a higher level of discrimination in evaluating genetic diversity in pawpaw and/or pawpaw has greater levels of genetic diversity than previously found.

The genus Asimina is the only temperate representative of the tropical Annonaceae, or Custard Apple family, and includes eight species, Asimina triloba (L.) Dunal., A. parviflora (Michx.) Dunal., A. incana (Bartr.) Exell., A. obovata (Willd.) Nash, A. reticulata Shuttlw. ex Chapman, $A$.tetramera Small, A. pygmaea (Bartr.) Dunal, and A. longifolia Kral, that are indigenous to North America (Kral, 1960; Peterson, 1991). The best-known species is Asimina triloba, the North American pawpaw, which has the largest edible fruit native to the United States (Darrow, 1975). This species is diploid [ $\mathrm{n}=2 \mathrm{x}=18$, (Bowden, 1948; Kral, 1960)], outcrosses (Willson and Schemske, 1980), and is pollinated by flies and beetles (Faegri and van der Piji, 1971). The pawpaw fruit is very nutritious (Peterson et al., 1982) and has an almost tropical aroma and smooth, custard-like texture, with flavors reminiscent of a combination of mango, banana, and pineapple (Layne, 1996; Shiota, 1991). The high fruit quality and attractive ornamental appearance give the pawpaw great potential as a commercial tree fruit or as a component in landscapes (Layne, 1996; Pomper et al., 1999).

From about 1900 to 1960 , at least 56 pawpaw cultivars were selected and named (Peterson, 1991). However, fewer than 20 of these selections remain, with many being lost from cultivation through neglect, abandonment of collections, and loss of

Received 1 Nov. 2002. Accepted 12 Mar. 2003. This research was supported by U.S. Dept. of Agriculture, Cooperative State Research, Education, and Extension Service Agreement no. KYX-9702815.

'Principal investigator of horticulture and curator, USDA National Clonal Germplasm Repository for Asimina spp., Kentucky State University, and President of The PawPaw Foundation. To whom reprint requests should be addressed. ${ }^{2}$ Research assistant, Horticulture Program, Kentucky State University. ${ }^{3}$ Former research assistant, Horticulture Program, Kentucky State University. ${ }^{4}$ Former graduate student, Horticulture Program, Kentucky State University and Dept. of Horticulture at the Univ. of Kentucky.

${ }^{5}$ Assistant professor of pomology and extension tree fruit specialist. records necessary for identification (Peterson, 1991). Since 1960, additional pawpaw cultivars have been selected from the wild or developed as a result of breeding efforts of hobbyists. More than 40 cultivars are currently commercially available (Jones et al., 1998). The loss of cultivars over the last century may have led to erosion in the genetic base of current pawpaw cultivars (Huang et al., 1997).

In 1994, Kentucky State University (KSU) was designated as a satellite repository for Asimina preservation in the U.S. Department of Agriculture (USDA), National Plant Germplasm System (NPGS). Germplasm evaluation, preservation, and dissemination have been a high priority at KSU since that time. The repository orchards currently contain over 1700 accessions collected from the wild in 17 states and more than 40 cultivars. One of the goals of the repository is to assess levels of genetic diversity in native populations and commercially available cultivars. Another goal is to acquire unique germplasm to include in our repository collection. Such material could be useful in future pawpaw breeding efforts.

A range of molecular markers has been used in attempts to evaluate genetic diversity in pawpaw. Rogstad et al. (1991) used a minisatellite probe, M13, to determine the genetic variation in pawpaw collected in five states. Using data from one to 22 samples per population, these authors examined genetic variation at sixteen sites both within and among populations. They determined that genetic variation is very low within populations, but moderate genetic variation occurred between populations, attributed to the geographical range of the species. They concluded that the low level of genetic variation within populations might be due to clonality or inbreeding. However, inbreeding is considered to be rare in pawpaw's reproductive biology, because it is most likely self-incompatible and therefore may require out-crossing (Norman et al., 1992; Peterson, 1991). Huang et al. (1997) used 
Table 1. Genetic background of 19 pawpaw (Asimina triloba) selections.

\begin{tabular}{ll}
\hline Cultivar & Genetic background \\
\hline 1) Cales Creek & Wild seedling from Summers Co., W. Va. \\
2) Davis & Wild seedling from Eaton Rapids, Mich. \\
3) Greenriver Belle Wild seedling from Hart County, Ky. \\
\begin{tabular}{ll} 
4) IXL & Seedling of 'Overleese' female X 'Davis' male \\
& selected in Eaton Rapids, Mich. \\
5) Middletown & Wild seedling from Middletown, Ohio. \\
6) Mitchell & Wild seedling from Iuka, Ill. \\
7) NC-1 & 'Davis' female X 'Overleese' male selected in \\
& Ontario, Canada. \\
8) Overleese & Seedling from Rushville, Ind. \\
9) PA-Golden(\#1) & Seedling from G.A. Zimmerman collection \\
& selected in Amherst, N.Y. \\
10) Prolific & Seedling from Eaton Rapids, Mich. \\
11) Rebecca's Gold & Seedling from Eaton Rapids, Mich. \\
12) SAA-Zimmerman & Seedling from G.A. Zimmerman collection \\
& selected in Amherst, N.Y. \\
13) Sue & Wild seedling from Ind. \\
14) Sunflower & Wild seedling from Chanute, Kans. \\
15) Sweet Alice & Wild seedling from W. Va. \\
16) Taylor & Wild seedling from Eaton Rapids, Mich. \\
17) Taytwo & Wild seedling from Eaton Rapids, Mich. \\
18) Wells & Cultivated seedlings (open pollinated) from \\
& Salem, Ind. \\
19) Wilson & Wild seedling from Cumberland, Ky. \\
\hline
\end{tabular}
\end{tabular}

isozymes to evaluate the genetic diversity represented in 32 pawpaw cultivars and advanced selections from the breeding program of R. Neal Peterson of the PawPaw Foundation. These authors determined that the isozyme marker variation in cultivated pawpaw is comparable to those of other long-lived temperate woody perennials of widespread geographic range with insect-pollinated outcrossing breeding systems, secondary asexual reproduction and animal-dispersed seed, thus having a higher level of genetic diversity than Rogstad et al. (1991) had reported. Huang et al. (1997) acknowledged that the results may have been impacted by non-random selection because several of the trees studied may have been purposely selected by pawpaw enthusiasts for desirable characteristics such as large fruit size or good growth vigor. Using isozymes, Huang et al. (1998) also assessed the level of genetic diversity within wild collected pawpaw accessions at KSU and examined genetic diversity between pawpaw populations from different geographical locations. Isozymes were used to score 23 loci using 25 to 50 trees from each of nine populations. The level of genetic variation found in KSU repository accessions was similar to that found in cultivated pawpaws (Huang et al., 1997). Using 12 randomly amplified polymorphic DNA (RAPD) primers, Huang et al. (2000) identified 21 Mendelian markers and determined that the level of genetic diversity in six populations in the KSU repository collection was higher than determined for pawpaw by the same authors using isozymes (Huang et al., 1997, 1998). Huang et al. (2003) have also used additional RAPD markers for fingerprinting pawpaw cultivars and reported similar levels of genetic diversity in cultivated pawpaw, in terms of Nei's genetic diversity constant $\left(\mathrm{H}_{\mathrm{e}}\right)$, to that reported for wild pawpaw populations by Huang et al. (2000).

Microsatellites, or simple sequence repeats (SSRs), are abundant throughout eukaryotic genomes (Kijas et al., 1995). The inter-simple sequence repeat PCR (ISSR-PCR) methodology uses a primer composed of a specific microsatellite sequence anchored at either the 3' or 5' end to amplify scorable DNA products (Gupta et al., 1994; Zietkiewicz et al., 1994). ISSR-PCR uses longer primers and has higher annealing temperatures than RAPD markers. It also has a higher degree of polymorphisms and reproducibility than do RAPD markers (Fang and Roose, 1997; Meyer et al, 1993). SSRs have become the marker system of choice for genetic diversity studies of many crops, such as apple [Malus $\times$ sylvestris (L.) Mill. Var. domestica (Borkh) Mansf.] (Gianfranceschi et al., 1998) and pear (Pyrus L.) (Yamamoto et al., 2001), due to their abundance in the genome and high degree of polymorphism (Weber and May, 1989). ISSR-PCR, which uses the occurrence of SSRs in the plant genome, has been used successfully to characterize genetic diversity within and among plant populations (Qian et al., 2001). The primary objectives of this study were to identify ISSR markers that segregate in a simple Mendelian fashion and use these markers to evaluate the genetic diversity in commercially available pawpaw cultivars. We were also interested in comparing diversity estimates with those previously reported for pawpaw using isozymes and RAPD markers.

\section{Materials and Methods}

Plant material. Dormant cuttings were collected in midMarch from pawpaw trees located at the KSU Repository for Asimina species in Frankfort, Ky., placed in beakers of distilled water, and placed under fluorescent room lighting at room temperature $\left(21^{\circ} \mathrm{C}\right)$ to force bud break and leaf growth. Additional leaves were also collected from plants in the field in mid-April. Leaf material was collected from the 34 progeny of controlled crosses (22 from 1-7-1 $\times 2-54$ and 12 from the progeny of the reciprocal cross) and from the individual parents 1-7-1 and 254 . For the genetic diversity study, leaf samples were collected from 19 commercially available pawpaw cultivars spanning the native range of pawpaw (Table 1). Leaf samples of the pawpaw cultivars Greenriver Belle, Sue, and IXL were obtained from a private nursery (Nolin River Nut Tree Nursery, Nolin River, Ky.). Samples of all other cultivars were obtained from the KSU repository orchards in Frankfort, Ky.

DNA EXTRACTION. DNA was extracted from the leaves using the Promega Wizard Genomic DNA purification kit (Promega Co., Madison, Wis.). About $50 \mathrm{mg}$ of leaf tissue was ground in a mortar with dry ice, and transferred to a $1.5 \mathrm{~mL}$ microfuge tube. Nuclei lysis solution was added $(600 \mu \mathrm{L} /$ tube $)$, vortexed for 1 to $3 \mathrm{~s}$ and samples incubated for $15 \mathrm{~min}$ at $65^{\circ} \mathrm{C}$. Two microliters RNase A (10 mg $\cdot \mathrm{mL}^{-1}$; Sigma Chemical Co., St. Louis, Mo.) was added to each sample, and the tube incubated for $15 \mathrm{~min}$ at $37^{\circ} \mathrm{C}$. Samples were cooled for 1 to $5 \mathrm{~min}$ on ice, and $200 \mu \mathrm{L}$ protein precipitation solution was added. Samples were vortexed for 20 $\mathrm{s}$, centrifuged $\left(15,800 \mathrm{~g}_{\mathrm{n}}\right)$ for $5 \mathrm{~min}$, then $750 \mu \mathrm{L}$ of supernatant was transferred to a tube containing $750 \mu \mathrm{L} 99 \%$ isopropanol. Samples were mixed by inversion and centrifuged for $5 \mathrm{~min}$. Supernatants were discarded and the DNA pellets were first washed with $500 \mu \mathrm{L}$ of $70 \%$ ethanol, next with $500 \mu \mathrm{L}$ of $95 \%$ ethanol and finally air dried for $15 \mathrm{~min}$. The DNA was solubilized in $150 \mu \mathrm{L}$ of $1 \times$ TE (10 mm Tris-HCl, 1 mm EDTA, pH 8.0) buffer by an initial incubation at $65{ }^{\circ} \mathrm{C}$ for $1 \mathrm{~h}$, then overnight at $4{ }^{\circ} \mathrm{C}$. The samples were centrifuged for $3 \mathrm{~min}\left(15,800 \mathrm{~g}_{\mathrm{n}}\right)$ to remove insoluble material and the supernatants were transferred to new tubes. The DNA concentration and a 260/280 nm absorbance ratio were determined using a GeneQuant RNA/DNA calculator spectrophotometer (Pharmacia Biotech, Cambridge, U.K.). All samples were stored at $-80{ }^{\circ} \mathrm{C}$ until needed.

ISSR-PCR AMPLIFICATION. The PCR reaction mixture contained 
Table 2. Single locus segregation and chi-square tests for 11 ISSR markers identified in the pawpaw (Asimina triloba) cross 1-7-1 x 2-54 and the reciprocal cross.

\begin{tabular}{|c|c|c|c|c|c|c|}
\hline \multirow[b]{3}{*}{ Locus } & \multirow{3}{*}{$\begin{array}{c}\text { Parents } \\
\text { ISSR } \\
\text { banding } \\
\text { phenotype }\end{array}$} & \multirow{3}{*}{$\begin{array}{c}\text { ISSR } \\
\text { genotype }\end{array}$} & \multicolumn{2}{|c|}{ Progeny } & \multirow{3}{*}{$\begin{array}{l}\text { Expected } \\
\text { ratio }\end{array}$} & \multirow[b]{3}{*}{$\chi^{2}$} \\
\hline & & & \multicolumn{2}{|c|}{$\begin{array}{l}\text { Phenotype } \\
\text { (genotype) }\end{array}$} & & \\
\hline & & & $1(+/+$ or $+/-)$ & $0(-/-)$ & & \\
\hline UBC812-0640 & $1 \times 0$ & $(+/+$ or $+/-\times-/-)$ & $15^{z}(8)^{x}$ & $19(4)$ & $1: 1$ & 0.53 \\
\hline UBC825-0760 & $1 \times 1$ & $(+/+$ or $+/-\times+/+$ or $+/-)$ & $22(8)$ & $12(4)$ & $3: 1$ & 2.17 \\
\hline UBC825-0696 & $1 \times 0$ & $(+/+$ or $+/-\times-/-)$ & $13(4)$ & $21(8)$ & $1: 1$ & 2.13 \\
\hline UBC841-1075 & $1 \times 0$ & $(+/+$ or $+/-\times-/-)$ & $19(7)$ & $15(5)$ & $1: 1$ & 0.53 \\
\hline UBC841-0480 & $1 \times 0$ & $(+/+$ or $+/-\times-/-)$ & $17(5)$ & $17(7)$ & $1: 1$ & 0.00 \\
\hline UBC853-1930 & $1 \times 0$ & $(+/+$ or $+/-\times-/-)$ & $18(7)$ & $16(5)$ & $1: 1$ & 0.13 \\
\hline UBC860-0875 & $1 \times 0$ & $(+/+$ or $+/-\times-/-)$ & $13(4)$ & $21(8)$ & $1: 1$ & 2.13 \\
\hline UBC860-0940 & $1 \times 0$ & $(+/+$ or $+/-\times-/-)$ & $17(8)$ & $17(4)$ & $1: 1$ & 0.00 \\
\hline UBC873-0480 & $1 \times 0$ & $(+/+$ or $+/-\times-/-)$ & $18(7)$ & $16(5)$ & $1: 1$ & 0.13 \\
\hline UBC873-0800 & $1 \times 1$ & $(+/+$ or $+/-\times+/+$ or $+/-)$ & $21(8)$ & $13(4)$ & $3: 1$ & 3.60 \\
\hline UBC880-1150 & $1 \times 1$ & $(+/+$ or $+/-\times+/+$ or $+/-)$ & $23(8)$ & $11(4)$ & $3: 1$ & 1.11 \\
\hline
\end{tabular}

zThe number of total individuals from the crosses 1-7-1 $\times 2-54$ and 2-54 $\times 1-7-1$ with the phenotype is shown.

xThe number of individuals from the 2-54 x 1-7-1 cross is listed in brackets for the phenotype shown.

10 mм Tris- $\mathrm{HCl}, \mathrm{pH}$ 9, 50 mм KCl, 0.1\% Triton X-100, $200 \mu \mathrm{m}$ dNTPs, 2 mM $\mathrm{MgCl}_{2}, 200$ nм primer, 1.5 units of Taq polymerase, and 2 ng DNA template in $20 \mu \mathrm{L}$ total volume. DNA was amplified using a GeneAmp PCR system 9700 (Perkin Elmer Applied Biosystems, Calif.). The program consisted of an initial period of $94{ }^{\circ} \mathrm{C}$ for $5 \mathrm{~min}$, followed by 45 cycles of $45 \mathrm{~s}$ at $94{ }^{\circ} \mathrm{C}, 1$ $\min$ at $50{ }^{\circ} \mathrm{C}$, and $2 \mathrm{~min}$ at $72{ }^{\circ} \mathrm{C}$ with a final extension period of $10 \mathrm{~min}$ at $72{ }^{\circ} \mathrm{C}$, followed by storage at $4{ }^{\circ} \mathrm{C}$ until use. The amplified products were electrophoresed at $4.5 \mathrm{~V} \cdot \mathrm{cm}^{-1}$ through a $1.4 \%$ agarose gel using a $1-\mathrm{kb}$ ladder as the molecular weight standard (Promega Co., Madison, Wis.). The gels were then stained using ethidum bromide and visualized under UV light. Photographs were taken using a Kodak digital camera and digital photos were analyzed using Kodak Digital Science ID software (Eastman Kodak Company, Rochester, N.Y.).

MARKER SCORING AND DATA ANALYSIS. ISSR primers (University of British Columbia, Canada, microsatellite set \#9) were screened against 34 progeny of a controlled cross and parents to identify segregating polymorphisms. Segregating ISSR markers were identified by the manufacturer primer code corresponding to the primer responsible for their amplification, followed by a four digit number indicating product size in base pairs (Table 2). ISSR phenotypes were scored as being either present (1) or absent (0) and the corresponding genotypes were assigned as $+/+$ or $+/-$ and $-/-$, respectively (Table 2 ). Genotypes that had a polymorphic band in at least two of three gels were scored as $+/+$ or $+/-$. Chisquare tests were used to determine the goodness-of-fit of these segregating polymorphisms to their expected Mendelian ratios $(n=34)$. Those with a $\chi^{2}$ value of $\geq 3.84$ were rejected.

Cultivars were screened for the presence of ISSR Mendelian markers that were identified in the segregating population (Table 2 ). Three replicate gels for cultivars were evaluated and scored for markers being either present (1) or absent (0). Cultivars having a specific Mendelian marker in at least two of three replicate gels were scored as having the marker present. For cultivars that had Mendelian markers in only one of three gels, an additional three gels were scored and genotypes with the marker in at least two of six gels were scored as having the marker present. Allele frequencies were indirectly estimated using the homozygous null genotypes (-/-) and corrected for dominance according to Lynch and Milligan (1994). Genetic statistics were estimated, corrected for small sample size (Nei, 1978), and used to determine the percentage of polymorphic loci $(P)(95 \%$ criterion) and expected heterozygosity $\left(H_{e}\right)$ (Miller, 1997). The level of genetic similarity among cultivars was determined by Nei's genetic distance (Nei, 1978). A dendrogram was constructed based on the matrix of the distances using unweighted pair-group mean analysis (UPGMA). Scores were entered in a matrix and analyzed with NTSYSpc software, version 2.02i (Exeter Software, Setauket, N.Y.). A similarity matrix was generated using the Dice coefficient, $\mathrm{S}=$ $2 \mathrm{Nxy} /(\mathrm{Nx}+\mathrm{Ny})$, where $\mathrm{Nx}$ and $\mathrm{Ny}$ are the numbers of bands observed in clones $\mathrm{X}$ and $\mathrm{Y}$, respectively, and Nxy is the number of bands common to both clones (Dice, 1945). The Dice values were then used to perform UPGMA cluster analysis and generate a dendrogram.

\section{Results and Discussion}

Eighty ISSR primers were screened that yielded a total of 234 amplified products. Of these 234 products, 30 polymorphic markers were found, and 11 of these segregated in a simple Mendelian fashion, as confirmed by chi-square analysis (Table 2). The 11 ISSR loci confirmed for Mendelian inheritance were used to assess genetic diversity in 19 pawpaw cultivars (Table 3). Marker UBC873-0800 had unreliable amplification and was not included in genetic diversity or cultivar separation analysis. Marker UBC860-0940 was present in all cultivars and UBC8250760 was present in all but one cultivar (Sunflower), while the 8 remaining markers showed a high degree of polymorphism (Table 3 ). Isozyme marker variation analysis in cultivated pawpaw suggested genetic diversity components that are comparable to those of other long-lived temperate woody perennials of widespread geographic range with insect-pollinated outcrossing breeding systems, secondary asexual reproduction and animal-dispersed seed (Huang et al. 1997, 1998) (Table 4). Using the 10 ISSR markers, estimates of genetic diversity $\left(P=80 \%\right.$ and $H_{e}=$ $0.358)$ were higher than those based on isozymes $(P=44 \%$ and $H_{e}=0.172$ ) for cultivated pawpaw, for RAPD markers for wild pawpaw accessions $\left(P=64 \%\right.$ and $\left.H_{e}=0.249\right)$ and cultivated pawpaw $\left(H_{e}=0.285\right)$ by Huang et al. $(1997,2000,2003)$ (Table 4). However, care must be taken in comparing the ISSR genetic diversity estimates to those of Huang et al. (1997, 2000). Six additional pawpaw cultivars were included in this study that were not included in the isozyme study of Huang et al. (1997); 
Table 3. ISSR markers scored in 19 pawpaw (Asimina triloba) cultivars.

\begin{tabular}{|c|c|c|c|c|c|c|c|c|c|c|c|c|c|c|c|c|c|c|c|}
\hline \multirow[b]{2}{*}{ Marker $^{\mathrm{y}}$} & \multicolumn{19}{|c|}{ Cultivar $^{z}$} \\
\hline & 1 & 2 & 3 & 4 & 5 & 6 & 7 & 8 & 9 & 10 & 11 & 12 & 13 & 14 & 15 & 16 & 17 & 18 & 19 \\
\hline UBC812-0640 & $1^{x}$ & 1 & 0 & 0 & 1 & 0 & 1 & 1 & 0 & 0 & 1 & 0 & 0 & 0 & 0 & 0 & 1 & 1 & 0 \\
\hline UBC825-0696 & 1 & 0 & 0 & 0 & 1 & 0 & 0 & 0 & 1 & 0 & 0 & 0 & 1 & 1 & 0 & 0 & 0 & 0 & 0 \\
\hline UBC825-0760 & 1 & 1 & 1 & 1 & 1 & 1 & 1 & 1 & 1 & 1 & 1 & 1 & 1 & 0 & 1 & 1 & 1 & 1 & 1 \\
\hline UBC841-o480 & 0 & 1 & 0 & 1 & 0 & 0 & 0 & 1 & 0 & 1 & 0 & 1 & 0 & 0 & 1 & 1 & 1 & 0 & 1 \\
\hline UBC841-1075 & 0 & 0 & 1 & 0 & 0 & 0 & 0 & 0 & 0 & 0 & 0 & 0 & 1 & 1 & 1 & 0 & 0 & 0 & 0 \\
\hline UBC853-1930 & 0 & 0 & 0 & 0 & 0 & 0 & 0 & 0 & 0 & 0 & 0 & 0 & 0 & 0 & 1 & 1 & 0 & 0 & 0 \\
\hline UBC860-0875 & 0 & 0 & 1 & 0 & 0 & 0 & 1 & 1 & 0 & 1 & 1 & 0 & 0 & 1 & 0 & 1 & 0 & 0 & 0 \\
\hline UBC860-0940 & 1 & 1 & 1 & 1 & 1 & 1 & 1 & 1 & 1 & 1 & 1 & 1 & 1 & 1 & 1 & 1 & 1 & 1 & 1 \\
\hline UBC873-0480 & 0 & 1 & 0 & 1 & 0 & 0 & 0 & 1 & 1 & 1 & 0 & 0 & 0 & 0 & 0 & 0 & 1 & 0 & 0 \\
\hline UBC880-1150 & 1 & 1 & 0 & 1 & 1 & 1 & 1 & 1 & 0 & 1 & 1 & 1 & 1 & 1 & 1 & 1 & 1 & 0 & 1 \\
\hline
\end{tabular}

zCultivar numbers correspond to those in Table 1 .

y Segregating ISSR markers were identified by the manufacturer primer code corresponding to the primer responsible for their amplification, followed by a four digit number indicating product size in base pairs

$\times 0=$ the marker was absent and $1=$ marker was present in the cultivar.

however, their isozyme study included 15 advanced selections from the PawPaw Foundation breeding effort and 2 cultivars that were not included in this ISSR study. Huang et al. (2000) used 21 RAPD markers that segregated in a simple Mendelain fashion and used 6 populations (10 to 18 trees each) from 6 states in the KSU repository collection to evaluate genetic diversity. Direct comparisons of the effectiveness of all three marker systems would require the use of these marker systems with the same genotypes. However, it would appear that the 10 ISSR loci had a higher level of polymorphism than the nine isozyme markers of Huang et al. (1997). Previous studies did not support the idea that high levels of genetic variation could be maintained in A. triloba, due to its clonal reproductive habit and low seed set in nature (Rogstad et al., 1991). This study provides additional evidence that moderate to high levels of genetic diversity exist in A. triloba (Huang et al. 1997, 1998, 2000).

The ISSR markers could be useful tools in cultivar identification. Using Nei's (1978) genetic distance, 11 of the 19 cultivars were uniquely identified (Fig. 1). The ISSR based UPGMA dendrogram showing genetic similarity among 19 pawpaw cultivars using separation by Dice (1945) was very similar to the separation using Nei's (1978) genetic distance (data not shown). The ISSR separation confirms the findings of Huang et al. (1997, 2003), in that the cultivar NC-1, which has been thought to be a seedling of a 'Davis' $x$ 'Oversleese' cross, does not share many markers with these cultivars. A mix up of pollen or seed must have occurred and NC-1 may have a different parentage than that reported. The cultivar IXL, which is thought to be a seedling of an 'Overleese' $X$ 'Davis' cross, did show some genetic similarity with these parents. Genetic relationships for the remaining cultivars in this study were similar to those found by Huang et al. with isozymes (1997) and RAPD markers (2003). The pawpaw cultivars SAA-Zimmerman and Mitchell, Prolific and Taytwo, and Sweet Alice and SAA-Zimmerman, shared similar grouping in both the dendrograms of Huang et al. (2003) (Fig. 1). Additional ISSR Mendelian markers could further improve genetic diversity estimates in pawpaw cultivars. We

Table 4. Comparison of genetic variation of pawpaw (Asimina triloba) with plant species having the same characteristics.

Species

characteristics

Life form: long-lived woody perennial ${ }^{2}$

Regional distribution: widespread $^{2}$

Geographic range: temperate ${ }^{z}$

Breeding system: outcrossing-animal ${ }^{2}$

Seed dispersal: animal ingested ${ }^{2}$

Mode of reproduction: sexual and asexual ${ }^{2}$

Average of all characteristics ${ }^{z}$

California cherimoya ${ }^{x}$

California and Spanish cherimoyaw

Cultivated pawpaw (Isozymes)

Pawpaw wild accessions (Isozymes)u

Pawpaw wild accessions (RAPDs) ${ }^{\mathrm{t}}$

Cultivated pawpaw (RAPDs)

Cultivated pawpaw (ISSRs)

\begin{tabular}{cc}
$\begin{array}{c}\text { Polymorphic } \\
\text { locus } \\
(\%)(\mathrm{P}) \mathrm{y}\end{array}$ & $\begin{array}{c}\text { Expected } \\
\text { heterzygosity } \\
\left(\mathrm{H}_{\mathrm{e}}\right)\end{array}$ \\
\hline $64.7 \pm 2.7$ & $0.177 \pm 0.010$ \\
$58.9 \pm 3.1$ & $0.202 \pm 0.015$ \\
$48.5 \pm 1.5$ & $0.146 \pm 0.000$ \\
$50.1 \pm 2.0$ & $0.167 \pm 0.010$ \\
$45.7 \pm 3.9$ & $0.176 \pm 0.019$ \\
$43.8 \pm 3.7$ & $0.138 \pm 0.016$ \\
$51.2 \pm 8.2$ & $0.168 \pm 0.023$ \\
73.3 & $0.330 \pm 0.064$ \\
44.8 & $0.183 \pm 0.044$ \\
44.4 & $0.166 \pm 0.048$ \\
43.5 & $0.172 \pm 0.013$ \\
64 & $0.249 \pm 0.022$ \\
--- & $0.285 \pm 0.160$ \\
80 & $0.358 \pm 0.205$
\end{tabular}

${ }^{2}$ Data from Hamrick and Godt, 1989 derived from isozyme studies. \pm standard deviation.

yP is the percent polymorphic loci and $\mathrm{H}_{\mathrm{e}}$ the mean gene heterozygosity, respectively.

${ }^{x}$ Calculated by Huang et al. (1997) from the data published by Elstrand and Lee (1987) and included other three monomorphic loci.

wCalculated by Huang et al. (1997) from data published by Pascual et al. (1993) and included 16 other monomorphic loci.

"From Huang et al. (1997).

uFrom Huang et al. (1998).

tFrom Huang et al. (2000).

sFrom Huang et al. (2003). 


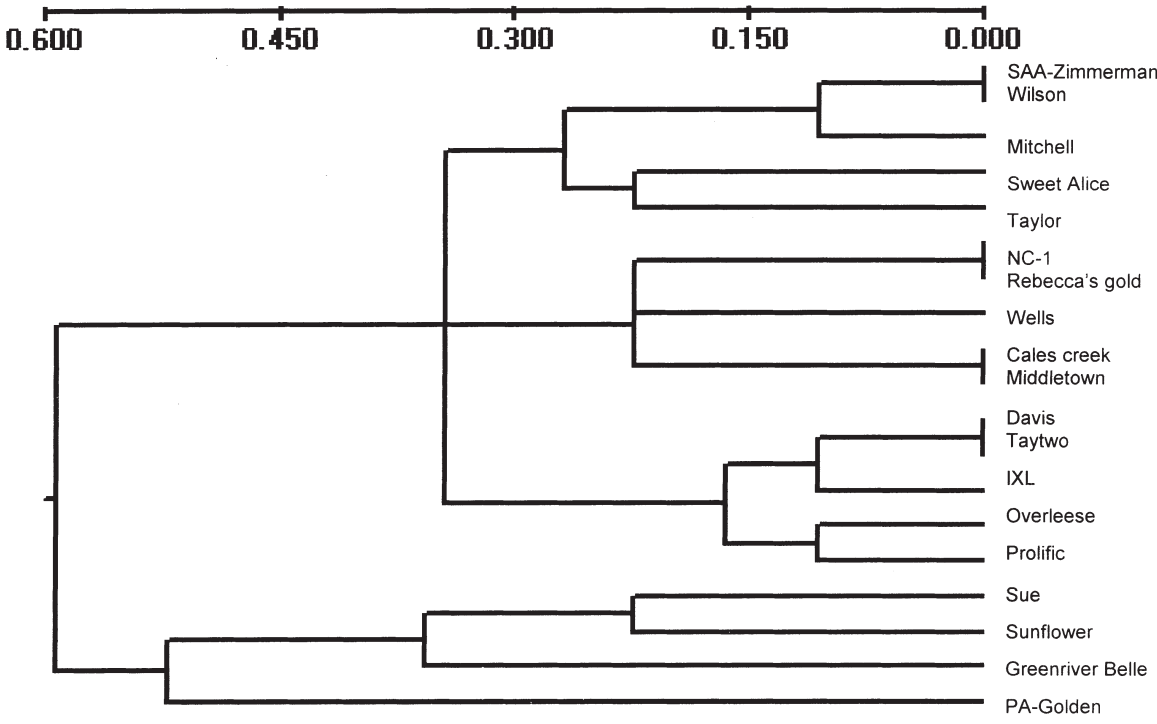

Fig. 1. ISSR based UPGMA dendrogram of Nei's (1978) genetic distance showing genetic similarity among 19 pawpaw (Asimina triloba) cultivars.

plan to identify additional and more reproducible ISSR markers to accurately fingerprint all pawpaw cultivars and separate remaining cultivar genetic identities.

In conclusion, seven primers yielded 11 Mendelian markers with either a $3: 1$ or $1: 1$ ratio that was confirmed by chi-square analysis. Using 10 ISSR Mendelian markers, an analysis of genetic diversity with leaf DNA samples collected from 19 pawpaw cultivars revealed a moderate to high level of genetic diversity in the selections. These data suggest that ISSR marker methodology has a higher level of discrimination in evaluating genetic diversity in pawpaw than do isozyme or RAPD marker systems.

\section{Literature Cited}

Bowden, W.M. 1948. Chromosome numbers in the Annonaceae. Amer. J. Bot. 35:377-381.

Darrow, G.M. 1975. Minor temperate fruits, p. 276-277. In: J. Janick and J.N. Moore (eds.). Advances in fruit breeding. Purdue Univ. Press, W. Lafayette, Ind.

Dice, L.R. 1945. Measures of the amount of ecological association between species. Ecology 26:297-302.

Ellstrand, N.C. and J.L. Lee. 1987. Cultivar identification of cherimoya (Annona cherimola Mill.) using isozyme markers. Scientia Hort. 32 $25-31$.

Faegri, K. and L. van der Piji. 1971. The principles of pollination ecology, p. 112-122. Pergammon, New York.

Fang, D.Q. and M.L. Roose. 1997. Identification of closely related citrus cultivars with inter-simple sequence repeat markers. Theor. Appl. Genet. 95:408-417.

Gianfranceschi L., N. Seglias, R. Tarchini, M. Komjanc, and C. Gessler 1998. Simple sequence repeats for the genetic analysis of apple. Theor. Appl. Genet. 96:1069-1076.

Gupta, M., Y.S. Chyi, J. Romero-Severson, and J.L. Owen. 1994. Amplification of DNA markers from evolutionary diverse genomes using single primers of simple-sequence repeats. Theor. Appl. Genet. 89: 998-1006.

Hamrick, J.L. and M.J.W. Godt. 1989. Allozyme diversity in plant species, p. 43-63. In A.H.D. Brown, M.T. Clegg, A.L. Kahler, and B.S Weir (eds.). Plant population genetics, breeding and genetic resources. Sinauer Associates, Inc., Publ., Sunderland, Mass.

Huang, H., D.R. Layne, and R.N. Peterson. 1997. Using isozyme polymorphisms foridentifying and assessing genetic variation in cultivated pawpaw [Asimina triloba (L.) Dunal]. J. Amer. Soc. Hort. Sci. 122:504-511.
Huang, H., D.R. Layne, and D.E. Riemenschneider. 1998. Genetic diversity and geographic differentiation in pawpaw [Asimina triloba (L.) Dunal] populations from nine states as revealed by allozyme analysis. J. Amer. Soc. Hort. Sci. 123:635-641.

Huang, H., D.R. Layne, and T.L. Kubisiak. 2000 RAPD inheritance and diversity in pawpaw (Asimina triloba). J. Amer. Soc. Hort. Sci. 125:454-459.

Huang, H., D.R. Layne, and T.L. Kubisiak. 2003. Molecular characterization of cultivated pawpaw (Asimina triloba) using RAPD markers. J. Amer. Soc. Hort. Sci. 128:85-93.

Jones, S.C, R. N. Peterson, T. Turner, K.W. Pomper, and D. R. Layne. 1998. Pawpaw planting guide: cultivars and nursery sources. KSU Pawpaw Ext. Bul. 001.

Kijas, J.M.H., J.C.S.Fowler, and M.R. Thomas. 1995 An evaluation of sequence-tagged microsatellite site markers for genetic analysis within Citrus and related species. Genome 38:349-355.

Kral, R. 1960. A revision of Asimina and Deeringothamnus (Annonaceae). Brittonia 12:233-278.

Layne, D.R. 1996. The pawpaw [Asimina triloba (L.) Dunal]: a new fruit crop for Kentucky and the United States. HortScience 31:777-784.

Lynch, M. and B.G. Milligan. 1994. Analysis of population genetic structure with RAPD J.C. markers. Mol. Ecol. 3:91-99.

Meyer,W., T.G. Mitchell,E.Z. Freedman, and R. Vilgays. 1993. Hybridization probes for conventional DNA fingerprinting used as single primers in the polymerase chain reaction to distinguish strains of Cryptococcus neoformans. J. Clin. Microbiol. 31:2274-2280.

Miller, M.P. 1997. Tools for population genetic analysis. v 1.3. Utah State Univ. Logan, Utah.

Nei, M. 1978. Estimation of average heterozygosity and genetic distance from a small number of individuals. Genetics 89:583-590.

Norman, E.M., K. Rice, and S. Cochran. 1992. Reproductive biology of Asimina parviflora (Annonaceae). Bull. Torrey Bot. Club. 119:1-5.

Pascual, L., F. Perfectti, M. Gutierrez, and A.M. Vargas. 1993. Characterizing isozymes of Spanish cherimoya cultivars. HortScience 28: 845-847.

Peterson, R.N., J.P. Cherry, and J.G. Simmons. 1982. Composition of pawpaw (Asimina triloba) fruit. Annu. Rpt. N. Nut Growers Assn. 73: 97-106.

Peterson, R.N. 1991. Pawpaw (Asimina). In: J.N. Moore and J.R. Ballington (eds.). Genetic resources of temperate fruit and nut crops. Acta Hort. 290:567-600.

Pomper, K.W., D.R. Layne, and R.N. Peterson. 1999. The pawpaw regional variety trial, p. 353-357. In J. Janick (ed.). Perspectives on new crops and new uses. ASHS Press, Alexandria, Va.

Qian, W., S. Ge, and D.Y. Hong. 2001. Genetic variation within and among populations of a wild rice Oryza granulata from China detected by RAPD and ISSR markers. Theor. Appl. Genet. 102:440-449.

Rogstad, S.H., K. Wolff, and B.A. Schaal. 1991. Geographical variation in Asimina triloba Dunal (Annonaceae) revealed by the M13 DNA fingerprinting probe. Amer. J. Bot. 78:1391-1396.

Shiota, H. 1991. Volatile components of pawpaw fruit (Asimina triloba Dunal.). J. Agr. Food Chem. 39:1631-1635.

Weber, J.L. and P.E. May. 1989. Abundant class of human DNA polymorphism which can be typed using the polymerase chain reaction. Amer. J. Human Genet. 44:388-396.

Willson, M.F. and D.W. Schemske. 1980. Pollinator limitation, fruit production, and floral display in pawpaw (Asimina triloba). Bul. Torrey Bot. Club 107:401-408.

Yamamoto, T., T. Kimura, Y. Sawamura, K. Kotobuki, Y. Ban, T. Hayashi, and N. Matsuta. 2001. SSRs isolated from apple can identify polymorphism and genetic diversity in pear. Theor. Appl. Genet. 102:865-870. Zeitkiewicz, E., A. Rafalski, and D. Labuda. 1994. Genome fingerprinting by simple sequence repeat (SSR)-anchored polymerase chain reaction amplification. Genomics 20:176-183. 